\title{
DEVELOPMENT OF A RAINFALL-RUNOFF MODEL: SUITABILITY ASSESSMENT IN THE MORAVA RIVER BASIN, CZECH REPUBLIC
}

\author{
KATERINA KNOPPOVA ${ }^{1,2}$ \& DANIEL MARTON ${ }^{1}$ \\ ${ }^{1}$ Institute of Landscape Water Management, Brno University of Technology, Czech Republic \\ ${ }^{2}$ Czech Hydrometeorological Institute, Czech Republic
}

\begin{abstract}
Availability of water as a natural resource is affected by the changing climate. To assess local hydrological impacts of climate change, less or more complicated hydrological models are being used. This paper presents a novel rainfall-runoff software, Runoff Prophet, which can simulate monthly discharge in a confluence of any river catchment. Usage of the model is based on monthly climatic and hydrological data as an input with no need of catchment characteristics description such as river slope, catchment slopes, land cover, river net system etc. Model calibration is based on differential evolution optimization algorithm, Thornthwaite evapotranspiration estimation method and set of water balance equations. The developed software was tested in complicated hydrological conditions in the Czech Republic. To assess universality of the newly developed software, model calibration and validation was performed and evaluated for catchments of different types across the Morava River Basin. The applicability of the software was tested for representative catchments classified into five pre-determined categories: i) agricultural, ii) forest, iii) mountain, iv) urbanised, and v) combined land use river basin. It was confirmed that Runoff Prophet is an effective tool for rainfall-runoff modelling with the purpose of long-term projection. In practice, it should be used for predictions of changes in hydrological balance of landscape or for estimations of future water supplies in reservoirs when assessing the current ones, as well as designing new ones.
\end{abstract}

Keywords: Runoff Prophet, rainfall-runoff model, lumped, hydrological modelling, Nash-Sutcliffe.

\section{INTRODUCTION}

In recent years, the impacts of climate change are being felt strongly in the Czech Republic. In future, these changes are expected to continue in the same extent and probably even deepen [1]. According to the Czech Hydrometeorological Institute preliminary press release [2], our country is still suffering from a dry period lasting since 2014. One of the indicators of drought is a low value of mean annual rainfall in comparison to long-term mean annual precipitation sum, which is $686 \mathrm{~mm}$ in the Czech Republic for the reference period 1981-2010. The most critical year in this dry period was 2015 with $187 \mathrm{~mm}$ mean annual rainfall deficit (28\%), and the year 2018 was evaluated as the second driest year with $171 \mathrm{~mm}$ deficit (25\%). With regards to the hydrological impact in the form of low river flows, the situation in the Czechia was worst in 2018 due to long-term accumulation of water deficit from previous years. For the Czech policymakers it is crucial to know whether the dry period is just a rare extremity or if one should expect serious problems due to lack of water in the future.

It is possible to make projections of future hydrological situation based on the available climate data predictions, provided that one is able to sufficiently describe the rainfall-runoff process in the particular catchment. The relationship between precipitation amount and river discharge is influenced by many factors, such as the basin area size and topography, hydrographic network, geological and soil parameters, land cover or the nature of the rainfall, temperature and soil moisture. It is a complex natural process and it is not a simple task to find clear relationships between climate data and discharges. 
Rainfall-runoff models are tools enabling simulation of this natural cycle. Many of them are based on description of the catchment characteristics, which tends to be one of the most challenging and time-consuming steps of hydrological modelling. This includes for example the models HEC-HMS [3], SAC-SMA [4], HYDROG [5], SWAT [6], TOPMODEL [7] and many others. The models are often locked without the possibility of advanced user custom modifications. They are quite complex, with strict requirements on input data quantity. However, it is possible to simulate rainfall-runoff process in an easier way, without having the catchment description available. Conceptual and empirical models are based on this counter-attitude. The relationship between cause and consequence is searched using calibration datasets of input elements. One of such models is also the Runoff Prophet [8], which was developed at the Institute of Landscape Water Management at Brno University of Technology.

The model is based on water balance equations used by Wang et al. [9] for large catchments in China, where the transition between a wet and dry season is quite evident. The original equations were successfully transferred to moderate climate conditions of the Czech Republic [10]-[12], where the hydrological regime significantly differs by its variability. This implies that the equations, and thus Runoff Prophet, could be transferable to similar basins in Temperate climate zones, and under certain circumstances worldwide.

Runoff Prophet was successfully tested on three case studies, but a systematic evaluation of the model efficiency has not yet been made. The aim of this paper is to examine the universality of the developed model and the equations used; and to find out whether it is applicable for catchments of different types across the Czech Republic natural conditions. The purpose of this paper is to determine whether the accuracy of the rainfall-runoff process simulation is affected by land use type of the river basin. The paper also attempts to ascertain the connections between model efficiency and the catchment area, number of available weather stations with satisfactory data and other individual catchment characteristics. The results of Runoff Prophet calibration and validation for 15 catchments classified into five representative land use types are presented.

\section{METHODS}

The basis of the developed hydrological model are the water balance equations used by Wang et al. [9]. They are intended for monthly calculation time step and cover two main components of total discharge from the basin: surface flow and groundwater flow. They also take into account potential evapotranspiration and soil moisture. In the basic form, they include four unknown variables: initial soil moisture $\mathrm{S}_{0}$, coefficient of surface flow $\mathrm{k}_{\mathrm{s}}$, coefficient of groundwater flow $\mathrm{kg}_{\mathrm{g}}$ and coefficient of evapotranspiration $\mathrm{k}_{\mathrm{e}}$.

For Runoff Prophet, monthly variability of calibration coefficients was selected. Thus there are 37 variables to be calibrated $-\mathrm{S}_{0}, 12 \mathrm{k}_{\mathrm{s}, \mathrm{i}}, 12 \mathrm{k}_{\mathrm{g}, \mathrm{i}}$ and $12 \mathrm{k}_{\mathrm{e}, \mathrm{i}}$, where $\mathrm{i}=1,2, \ldots, 12$ (January to December). To evaluate the chosen set of variables, the Nash-Sutcliffe model efficiency coefficient (NS) was used as a fitness function to be maximized. Model calibration is based on the differential evolution described in [13]. Evapotranspiration data, which are needed in the equations, are calculated from air temperature; in the software either by Thornthwaite [14] or Blaney-Criddle [15] method, in the paper by Thornthwaite only.

\section{RUNOFF PROPHET SOFTWARE}

Based on the above described methods, an application software Runoff Prophet was developed. Runoff Prophet is a rainfall-runoff model for simulations of river flow in catchment confluence. According to [16], it can be classified as a deterministic conceptual lumped model with monthly computing time step. The calculation requires no geographical 
characteristics of the catchment but its area. Firstly, the model is calibrated using historical climate and hydrological data, then it is possible to simulate future discharge based on predicted climate data.

Before hydrological modelling in a confluence of chosen river catchment, it is necessary to obtain required input data. Datasets related to the basin need to include monthly mean air temperature, monthly total precipitation and monthly mean water flow for calibration; monthly mean air temperature and monthly precipitation for subsequent prediction.

For the chosen catchment, localization is done first, which means specifying the basin area and geographical location of meteorological stations, where the used climate data comes from. Then a method of evapotranspiration estimation is chosen and settings of differential evolution parameters and upper limits of calibration coefficients are made. Afterwards, calibration can be run. Its success rate is quantified by the value of the NS criterion. When the model is calibrated for the basin, predictions can be executed.

\section{APPLICATION}

To evaluate the suitability of Runoff Prophet for different natural conditions, five categories of river basins covering the basic range of their typology were determined: i) agricultural (A), ii) forest (F), iii) mountain (M), iv) urbanised (U), and v) combined land use (C). For each category, several experimental catchments with hydrological measurements in its confluence were selected.

As area of interest, the Morava River basin was selected, being the Czech part of the first order basin of the Danube River. There are over 150 hydrometric stations in the Morava Basin owned by the Czech Hydrometeorological Institute (CHMI). Based on CHMI expert hydrologist's professional knowledge of the territory, 17 catchments of various size were chosen and classified into pre-determined categories (Fig. 1).

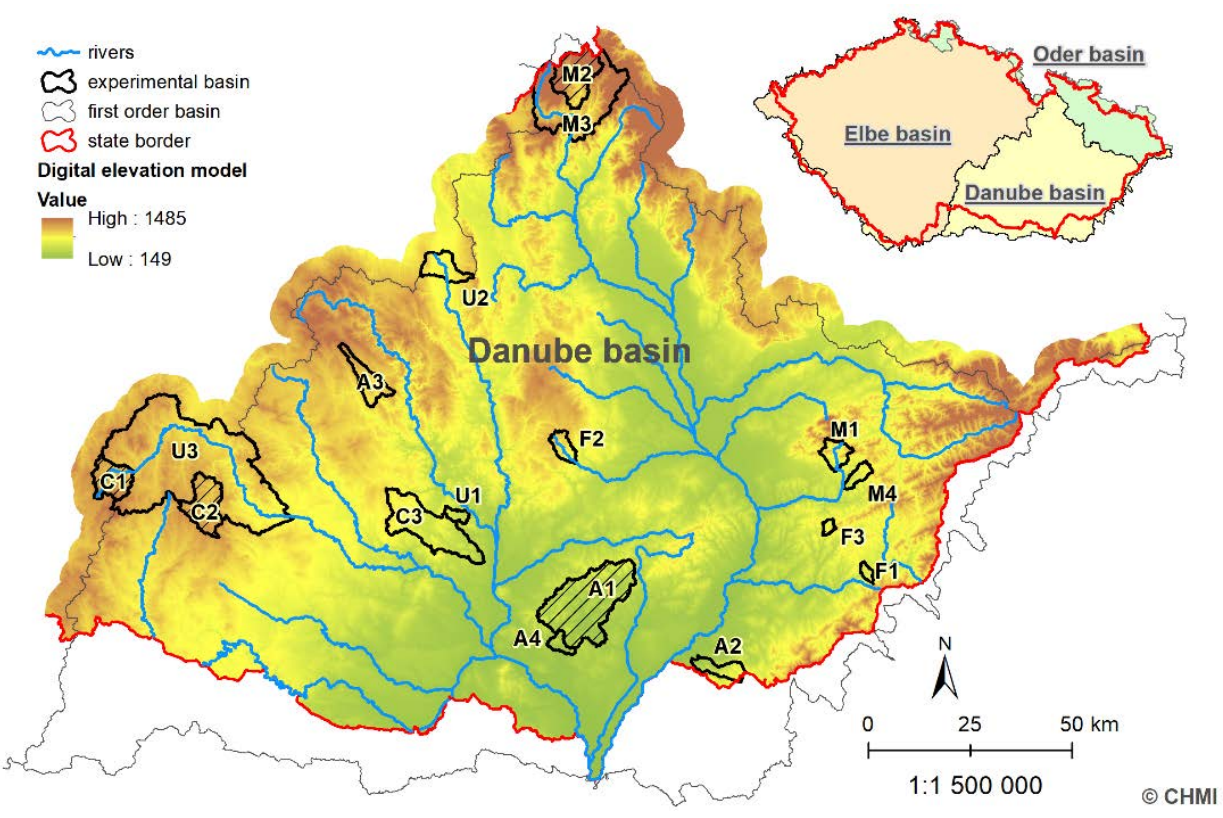

Figure 1: Chosen experimental catchments (CHMI). 
For the purposes of final assessment, each basin was assigned an ID according to its category. Rudimentary catchment characteristics quantified were: total area in $\mathrm{km}^{2}$, mean slope and proportions of forest, built-up area and arable land including orchards (Table 1).

Table 1: Selected catchments.

\begin{tabular}{|c|c|c|c|c|c|c|c|c|}
\hline \multicolumn{6}{|c|}{ Catchment characteristics } & \multicolumn{3}{|c|}{$\begin{array}{l}\text { Catchment area proportion } \\
\text { (CORINE Land Cover 2018) }\end{array}$} \\
\hline 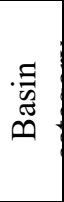 & $\begin{array}{c}\text { Basin } \\
\text { ID }\end{array}$ & $\begin{array}{c}\text { Hydrometric } \\
\text { station }\end{array}$ & River & $\begin{array}{l}\text { Total } \\
\text { area } \\
\left(\mathrm{km}^{2}\right)\end{array}$ & $\begin{array}{c}\text { Mean } \\
\text { slope } \\
(\%) \\
(\mathrm{DMR} \\
5 \mathrm{G})\end{array}$ & $\begin{array}{c}\text { Forest } \\
(\%)\end{array}$ & $\begin{array}{l}\text { Built-up } \\
\text { area (\%) }\end{array}$ & $\begin{array}{c}\text { Arable } \\
\text { land }+ \\
\text { Orchard } \\
(\%)\end{array}$ \\
\hline \multirow{4}{*}{ 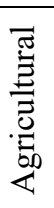 } & A1 & Bořetice & Trkmanka & 285.81 & 7.6 & 23.4 & 5.1 & 62.3 \\
\hline & $\mathrm{A} 2$ & Petrov & Radějovka & 41.02 & 7.1 & 39.6 & 1.8 & 26.4 \\
\hline & A3 & Rožná & Nedvědička & 57.19 & 5.6 & 19.7 & 4.4 & 58.9 \\
\hline & A4 & \begin{tabular}{|l} 
Velké \\
Pavlovice
\end{tabular} & Trkmanka & 304.59 & 7.6 & 22.4 & 5.1 & 62.0 \\
\hline \multirow{3}{*}{ 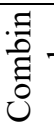 } & $\mathrm{C} 1$ & Batelov & Jihlava & 73.48 & 4.7 & 29.0 & 4.3 & 32.9 \\
\hline & $\mathrm{C} 2$ & Brtnice & Brtnička & 95.32 & 4.4 & 37.8 & 3.4 & 46.8 \\
\hline & $\mathrm{C} 3$ & Želešice & Bobrava & 181.52 & 7.5 & 48.6 & 9.0 & 38.0 \\
\hline \multirow{3}{*}{ 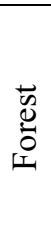 } & F1 & $\begin{array}{l}\text { Bojkovice } \\
\text { nad nádrží }\end{array}$ & Kolelač & 9.76 & 8.0 & 52.1 & 0.0 & 13.3 \\
\hline & $\mathrm{F} 2$ & $\begin{array}{l}\text { Opatovice } \\
\text { nad nádrží }\end{array}$ & Malá Haná & 30.92 & 7.7 & 60.2 & 2.4 & 31.5 \\
\hline & $\mathrm{F} 3$ & $\begin{array}{l}\text { Řetechov- } \\
\text { Pradlisko }\end{array}$ & $\begin{array}{l}\text { Ludkovický } \\
\text { potok }\end{array}$ & 8.45 & 12.2 & 47.4 & 5.2 & 6.3 \\
\hline \multirow{4}{*}{ 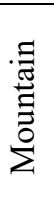 } & M1 & $\begin{array}{l}\text { Kašava nad } \\
\text { nádrží }\end{array}$ & Dřevnice & 36.70 & 14.3 & 75.9 & 2.5 & 0 \\
\hline & M2 & Habartice & Krupá & 109.35 & 13.6 & 61.4 & 0.8 & 0 \\
\hline & M3 & Raškov & Morava & 349.79 & 13.9 & $\begin{array}{l}51.7 \\
\end{array}$ & 1.1 & 0.2 \\
\hline & M4 & Slušovice & Všemínka & 21.22 & 13.3 & 53.4 & 9.4 & 0.4 \\
\hline \multirow{3}{*}{ 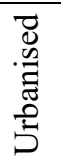 } & U1 & Bystrc & Vrbovec & 15.02 & 9.3 & 56.3 & 17.7 & 21.4 \\
\hline & U2 & $\begin{array}{l}\text { Hradec nad } \\
\text { Svitavou }\end{array}$ & Svitava & 55.20 & 3.7 & 18.3 & 11.1 & 61.1 \\
\hline & U3 & Ptáčov & Jihlava & 962.71 & 5.5 & 31.0 & 5.2 & 42.4 \\
\hline
\end{tabular}

\subsection{Data processing}

Hydrological and climate data for model calibration and validation had to be obtained for each catchment. CHMI provided observed data from the selected hydrometric stations and from all the current weather stations located in the area of chosen river basins and their surroundings. The climatological stations within the station network are not evenly spatially distributed and in addition, the size of the catchments varied, therefore the total number of usable weather stations for the individual basins was different. For each catchment, time series from 1 to 5 stations with temperature measurement and from 2 to 10 stations with rainfall measurement were identified and processed in order to find the best combination of temperature and precipitation input data for the hydrological model. 
Hydrological data from 17 hydrometric stations corresponding to the chosen catchments were required in the form of mean monthly river flow $\left(\mathrm{m}^{3} / \mathrm{s}\right)$ and were exported from the CHMI Hydrology department database. Datasets of mean monthly air temperature $\left({ }^{\circ} \mathrm{C}\right)$ from 32 stations and total monthly precipitation $(\mathrm{mm})$ from 63 stations were processed by CHMI Meteorology and climatology department. For the purposes of the experiments, different combinations of stations with different length of calibration/validation datasets had to be tested and evaluated. One combination contained data from one gauging station, one temperature station and one rainfall station. The combinations were created separately for each basin according to following criteria.

Mean water flow time series had to have at least 13 years of gauging data with simultaneous measurement of both temperature and rainfall data at one or more related weather stations. Temperature time series had to be at least 13 years long (during the period with available discharge data). If more stations fulfilled this condition, the ones with at least the same time series length as river flow were chosen. If there were more such stations, the one which was not evaluated as distant from the basin was chosen. If more stations with temperature data fulfilled the criteria, the combinations were prepared from all of them. Rainfall datasets had to be at least 13 years long (with simultaneous water flow measurement). Each satisfactory temperature dataset was combined with each satisfactory precipitation dataset and was complemented by the water flow data.

After applying all the criteria, the following number of weather stations was chosen (Table 2). Two of the stream gauging stations (A1 and $\mathrm{C} 2$ ) did not have measurement records long enough, hence they were excluded from further testing.

Table 2: Number of chosen discharge, temperature and precipitation weather stations.

\begin{tabular}{|c|c|c|c|}
\hline ID & Q Chosen & TEMP Possible/Chosen & RAIN Possible/Chosen \\
\hline A1 & 0 & $-/-$ & $-/-$ \\
\hline A2 & 1 & $1 / 1$ & $3 / 3$ \\
\hline A3 & 1 & $1 / 1$ & $3 / 3$ \\
\hline A4 & 1 & $3 / 1$ & $9 / 7$ \\
\hline C1 & 1 & $3 / 1$ & $2 / 1$ \\
\hline C2 & 0 & $-/-$ & $-/-$ \\
\hline C3 & 1 & $3 / 2$ & $3 / 3$ \\
\hline F1 & 1 & $5 / 1$ & $7 / 6$ \\
\hline F2 & 1 & $3 / 2$ & $5 / 4$ \\
\hline F3 & 1 & $2 / 1$ & $2 / 1$ \\
\hline M1 & 1 & $5 / 2$ & $8 / 7$ \\
\hline M2 & 1 & $5 / 1$ & $10 / 9$ \\
\hline M3 & 1 & $5 / 1$ & $10 / 9$ \\
\hline M4 & 1 & $5 / 2$ & $8 / 8$ \\
\hline U1 & 1 & $2 / 1$ & $4 / 3$ \\
\hline U2 & 1 & $1 / 1$ & $3 / 3$ \\
\hline U3 & 1 & $3 / 1$ & $4 / 2$ \\
\hline
\end{tabular}

Each combination had to be divided into different variants of calibration and validation dataset length. Minimal length of calibration time series was set to 10 years, further variants 
gradually being increased by five years $(10,15,20$, etc.). Calibration to validation dataset ratio was $3: 1$ as tested in [8], validation series length was rounded to the nearest whole year $(3,5,7$, etc.). Validation time series preceded the relevant calibration with no time gap (Fig. 2).

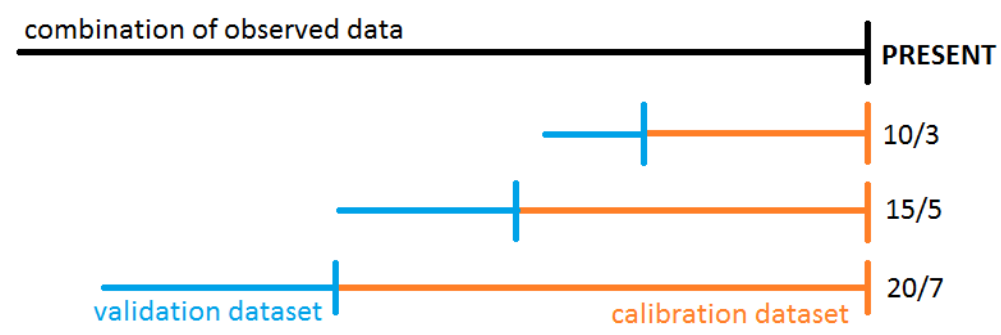

Figure 2: Scheme of calibration and validation datasets.

\subsection{Runoff Prophet calibration and validation}

For each basin, all the created combinations were evaluated using Runoff Prophet. Firstly, the calibration was run with calibration dataset as an input and its efficiency expressed by the NS was recorded. Then the validation was performed using temperature and rainfall data from the relevant validation dataset. Its NS was calculated from the comparison of predicted water flow and water flow from the validation dataset time series.

For all the experiments, Runoff Prophet settings were constant. Thornthwaite method for estimating evapotranspiration was used, the parameters of differential evolution and upper limits of calibration coefficients were both set to default.

\section{RESULTS AND DISCUSSION}

For the basins, all the datasets were evaluated by NS of calibration and NS of relevant validation. If NS of calibration and also validation exceeded 0.5 , the combination was rated as satisfactory [17]. For each catchment, the results of all the combinations were listed according to the highest value of validation NS. Optimal data sources and lengths are specified in Table 3.

From the 15 considered basins, eight were evaluated as satisfactory. For most of them, 10 years of calibration (three of validation) time series were evaluated as the optimal length. In one case, 15 years (five for validation) was the most suitable option, in three cases, it was 25 (six for validation).

The catchments had a different size across the defined categories, therefore there was a reason for examining its impact on model performance (Fig. 3). Coherent low model efficiency was recognised on the smallest basins. Calibration/validation on three catchments with area of less than $15 \mathrm{~km}^{2}$ was considered unsatisfactory. In two cases, NS of validation was very close to the satisfactory limit $(0.45$ on F3 and 0.48 on F1) and in all cases the basins fell into the problematic categories ( $\mathrm{F}$ and $\mathrm{U}$ ), as explained below.

A correlation between land use on the basin and satisfactory result of model calibration and validation was found across the categories. The catchments with more than $10 \%$ of urbanised area gave unsatisfactory result (two cases). Also the catchments with ratio of arable and orchard land of more than $60 \%$ had the resulting NS evaluated as unsatisfactory (two cases). 
Table 3: Results of best validation/calibration in the representative basins.

\begin{tabular}{|l|l|c|l|l|c|c|c|}
\hline \multicolumn{2}{|c|}{ Catchment characteristics } & \multicolumn{3}{c|}{ Optimal combination } & \multicolumn{2}{c|}{$\begin{array}{c}\text { NS } \\
\text { (Best VAL) }\end{array}$} \\
\hline ID & Hydrometric station & $\begin{array}{c}\text { Satisfac } \\
\text {-tory }\end{array}$ & TEMP & RAIN & $\begin{array}{l}\text { Length } \\
\text { (years) }\end{array}$ & CAL & VAL \\
\hline A2 & Petrov & Y & Strážnice & Strážnice & 10 & 0.83 & 0.73 \\
\hline A3 & Rožná & Y & $\begin{array}{l}\text { Bystřice nad } \\
\text { Pernštejnem }\end{array}$ & $\begin{array}{l}\text { Bystřice nad } \\
\text { Pernštejnem }\end{array}$ & 15 & 0.70 & 0.64 \\
\hline A4 & Velké Pavlovice & N & Pohořelice & Ždánice & 10 & 0.45 & 0.05 \\
\hline C1 & Batelov & Y & Počátky & Třešt' & 25 & 0.66 & 0.69 \\
\hline C3 & Želešice & Y & Troubsko & $\begin{array}{l}\text { Moravské } \\
\text { Bránice }\end{array}$ & 10 & 0.69 & 0.68 \\
\hline F1 & Bojkovice nad nádrží & N & Vizovice & Uherský Brod & 25 & 0.63 & 0.48 \\
\hline F2 & Opatovice nad nádrží & N & Protivanov & Blansko & 10 & 0.66 & 0.40 \\
\hline F3 & Řetechov-Pradlisko & N & Vizovice & Horní Lhota & 10 & 0.73 & 0.45 \\
\hline M1 & Kašava nad nádrží & Y & Vizovice & Zlín, Velíková & 10 & 0.75 & 0.73 \\
\hline M2 & Habartice & Y & Šerák & $\begin{array}{l}\text { Malá Morava, } \\
\text { Sklené }\end{array}$ & 10 & 0.78 & 0.53 \\
\hline M3 & Raškov & N & Šerák & Králíky & 10 & 0.63 & 0.46 \\
\hline M4 & Slušovice & Y & Vizovice & Zlín, Velíková & 10 & 0.72 & 0.74 \\
\hline U1 & Bystrc & N & Troubsko & Zastávka & 25 & 0.33 & -0.39 \\
\hline U2 & Hradec nad Svitavou & N & Gajer, Janov & Gajer, Janov & 10 & 0.55 & 0.38 \\
\hline U3 & Ptáčov & Y & Hubenov & Hubenov & 10 & 0.69 & 0.54 \\
\hline
\end{tabular}

\section{CATCHMENT AREA AND MODEL EFFICIENCY RELATION}
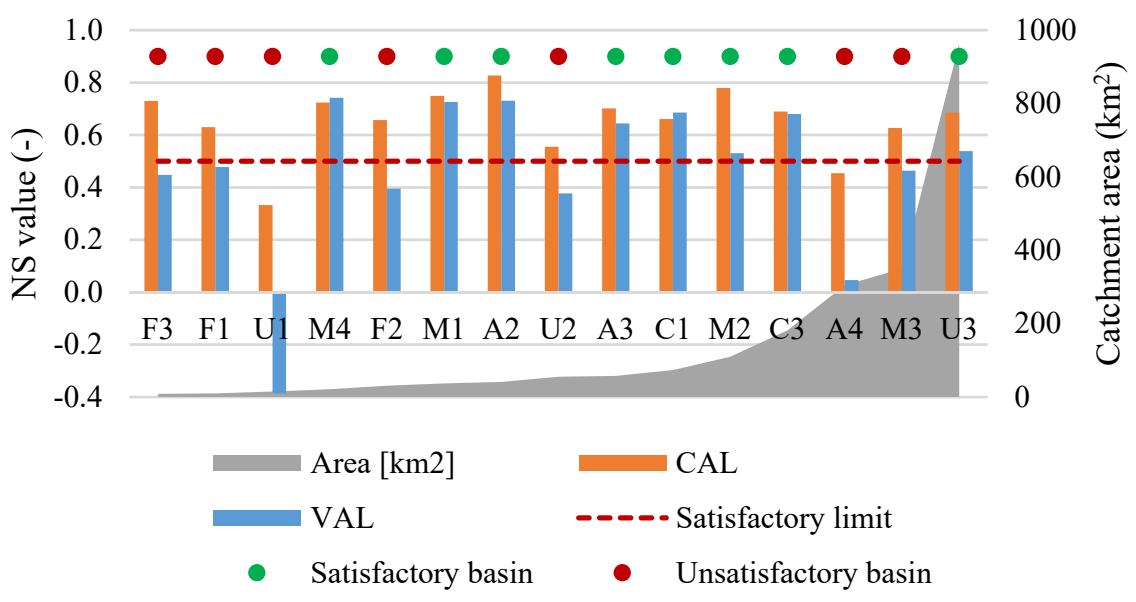

Figure 3: Relationship between catchment size and model efficiency (NS of calibration/validation from optimal combination). 
The representative basin categories were evaluated separately and the results of NS were rated in more detail according to [17]:

\subsection{Agricultural river basin (A)}

Two out of three catchments were evaluated as satisfactory. A2 had very good NS of calibration and good NS of validation, A3 good NS of calibration and satisfactory result of validation. For A4, the model did not succeed neither in the calibration, nor validation.

\subsection{Forest river basin $(\mathrm{F})$}

Runoff Prophet did not satisfactory simulate any of the chosen forest catchments. Even when NS coefficients of calibration were good or satisfactory, the validations were not successful and were evaluated between 0.4 and 0.48 .

\subsection{Mountain river basin (M)}

Three out of four catchments achieved satisfactory results. In all three cases, model performance was very good or good in terms of calibration and good or satisfactory in terms of validation. The unsatisfactory basin M3 was very close to fulfilling the limits, achieving NS of 0.63 for calibration and 0.46 for validation.

\subsection{Urbanised river basin (U)}

One of the three catchments fulfilled the satisfactory limit. Interestingly, it was Ptáčov (U3), the largest basin with a total area of $962.71 \mathrm{~km}^{2}$.

\subsection{Combined land use river basin (C)}

Both of the combined catchments met the satisfactory limit with a good value of NS for calibration as well as validation.

According to the NS results, Runoff Prophet performed very well on combined land use river basins and mountain river basins. Good results were also achieved for agricultural basins. Urbanised river basin category was problematic, with variable results and only one satisfactory case. The model was completely unsuccessful regarding forest basins, with consistent results of NS slightly below the specified limit.

Providing a clear explanation of poor results in the last two categories is not easy. Hydrological modelling on urbanised basins can be disputable due to anthropogenic influence on the rainfall-runoff process. Natural monthly relationships between precipitation, temperature and discharge can be disrupted by municipal water management, in particular water consumption, retention and draining. Regarding the forest basins, for assessment it is interesting to compare the catchments characteristics with very good resulting category of mountain basins. The ratio of forest land cover is $\geq 45 \%$ for both categories. Mountain basins have an even larger proportion of forest area. However, a significant difference between them is in the mean slope. Mountain basins have a mean slope of more than $13 \%$, the forest basins are not so steep - mean slope in this case is less than $13 \%$. There is also a difference between arable and orchard land area, where mountain category includes catchments with 0 to $1 \%$ of such area, whereas the chosen forest basins have $6-32 \%$ of arable land area. Large area of the forest can have significant impact on rainfall-runoff process and the insufficient coverage of weather stations may lead to inaccurate description of the 
precipitation nature. The model confirmed the presumption that in the mountain basins, precipitation is transformed into discharge faster due to steeper slopes and the significance of forest microclimate and small water cycle declines.

Another question is whether the number of available weather stations for the basin increases the accuracy of model calibration/validation results. Fig. 4 shows the number of satisfactory (+) and unsatisfactory (-) basins for different number of stations. A relationship was then searched for between the possible stations, i.e. before applying selection criteria, and also chosen stations.

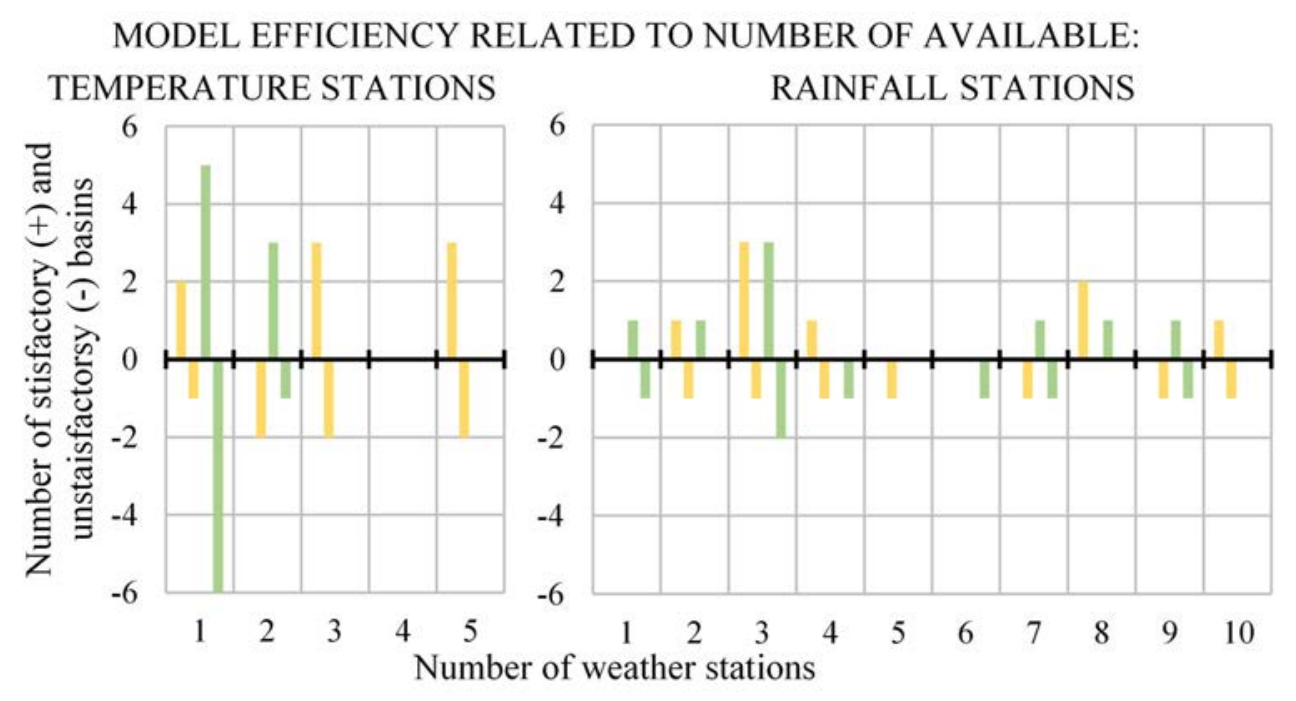

Possible stations $=$ Chosen stations

Figure 4: Model efficiency in relation to the number of available weather stations.

Concerning the temperature data, there is no visible correlation between the number of possible stations in the basin and the model result. For the chosen stations, more positive ratio of basins was evaluated as satisfactory for two stations $(3: 1)$ than for one (5:6). It was important to find out, if a good result of a basin is truly a consequence of more variants of used temperature data or if it is caused by catchment characteristics and easier conditions for hydrological modelling. On four catchments, two temperature stations passed the defined criteria and were used for creating variant calibration/validation datasets. Table 4 shows the results of best validation NS for two variants of temperature data source. As can be seen in the table below, satisfactoriness of the basin is same for both temperatures in case of all events. There is also no big difference between resulting NS of calibration and validation, ranging from $0-0.03$ for calibration and $0-0.06$ for validation.

With regards to the rainfall data, the relationship between the number of possible and chosen stations and satisfactoriness of the basin is non-determinable due to a high variability in the number of stations (Fig. 4). For more detailed insight, the relationship between available stations number and the resulting calibration and validation NS was examined. As can be seen in Fig. 5, there is no clear correlation between the number of chosen rainfall stations and the resulting NS or basin satisfactoriness. 
Table 4: NS results for basins with two variants of chosen temperature stations.

\begin{tabular}{|c|c|c|c|c|c|c|c|c|}
\hline \multirow{3}{*}{$\begin{array}{c}\text { Basin } \\
\text { ID }\end{array}$} & \multicolumn{3}{|c|}{ TEMP 1} & \multicolumn{3}{|c|}{ TEMP 2} & \multirow{2}{*}{\multicolumn{2}{|c|}{$\begin{array}{c}\text { Difference of NS } \\
\text { (Best VAL) }\end{array}$}} \\
\hline & \multicolumn{2}{|c|}{$\begin{array}{c}\text { NS } \\
\text { (Best VAL) }\end{array}$} & \multirow{2}{*}{$\begin{array}{l}\text { Satisfac } \\
\text { tory }\end{array}$} & \multicolumn{2}{|c|}{$\begin{array}{c}\mathrm{NS} \\
\text { (Best VAL) }\end{array}$} & \multirow{2}{*}{$\begin{array}{l}\text { Satisfac } \\
\text { tory }\end{array}$} & & \\
\hline & CAL & VAL & & CAL & VAL & & CAL & VAL \\
\hline F2 & 0.66 & 0.40 & $\mathrm{~N}$ & 0.69 & 0.33 & $\mathrm{~N}$ & 0.03 & -0.06 \\
\hline $\mathrm{C} 3$ & 0.69 & 0.68 & $\mathrm{Y}$ & 0.71 & 0.61 & $\mathrm{Y}$ & 0.02 & -0.07 \\
\hline M1 & 0.75 & 0.73 & $\mathrm{Y}$ & 0.75 & 0.71 & $\mathrm{Y}$ & 0.00 & -0.02 \\
\hline M4 & 0.72 & 0.74 & $\mathrm{Y}$ & 0.73 & 0.74 & $\mathrm{Y}$ & 0.00 & 0.00 \\
\hline
\end{tabular}

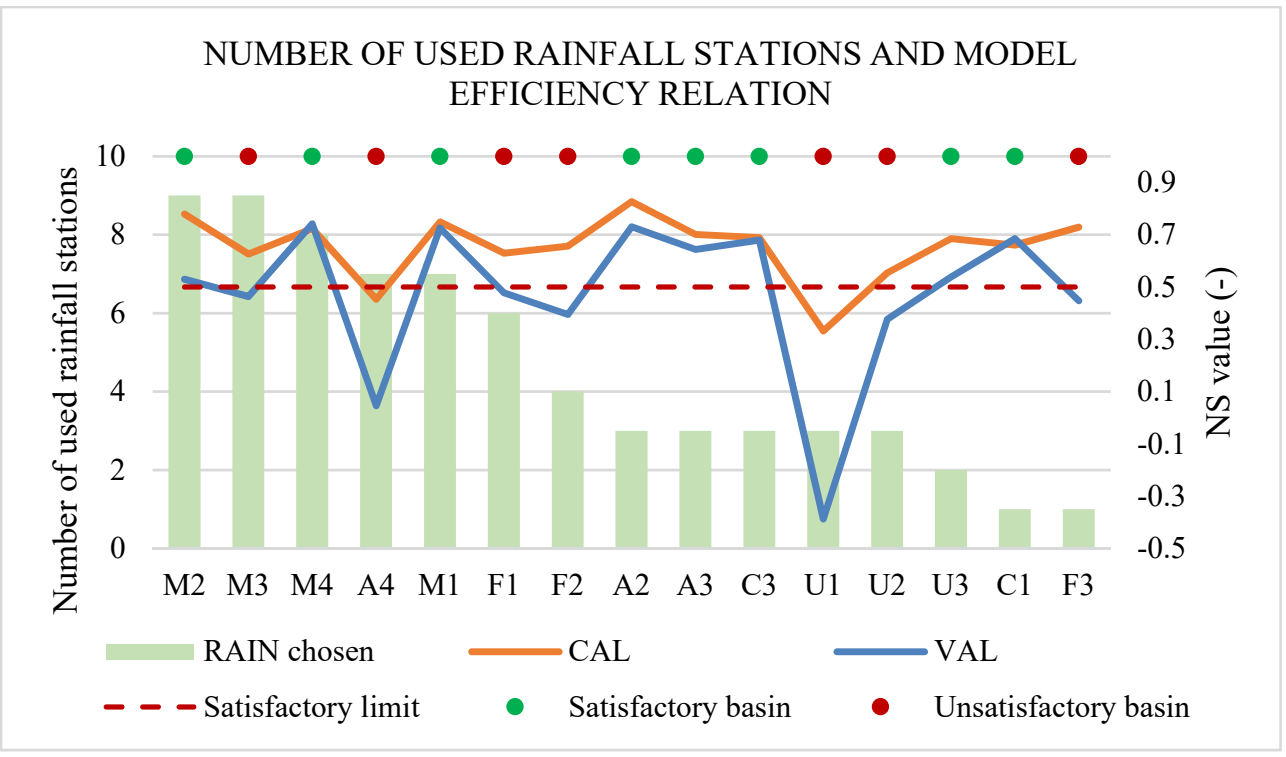

Figure 5: Relationship between the number of chosen rainfall stations and model efficiency.

It is important to note that the calibration for the experimental basins was run with the same default settings. It is likely that different basins would achieve reliable results with different upper limits of calibration coefficients and parameters of differential evolution.

Also a more robust method of model efficiency verification would be appropriate with more variants of calibration time periods and more validation datasets for each variant.

\section{CONCLUSION}

Runoff Prophet, a novel rainfall-runoff model developed at Brno University of Technology, was systematically tested to confirm its wide-range usability in various hydrological conditions in the Czech Republic. A set of representative catchments from the Morava River Basin, Czech part of the Danube Basin, was chosen. For these 15 catchments, Runoff Prophet was calibrated and validated across different combinations of input data source and time series length. Based on the achieved value of Nash-Sutcliffe model efficiency coefficient, an 
optimal combination of air temperature and precipitation input data was determined. Model performance for each catchment was rated as satisfactory or unsatisfactory. The results were evaluated from the perspective of river basin category, land use characteristics, area and number of available weather stations.

The results of the experiments presented in this paper showed that Runoff Prophet is more suitable for hydrological modelling of mountain river basins, agricultural river basins and river basins with combined land use. Its application on forest and urbanised river basins did not lead to satisfactory results. It was also shown, that there was no provable relationship between the size of catchment area and model calibration success. Based on the number of available stations, no effect of quantity of both air temperature and rainfall considered data sources on model performance was found. From the total number of 15 experimental basins, 8 were modelled with satisfactory results and 4 were very close to the satisfactory limit. In the light of catchments variability, this can be declared better-than-expected outcome, which could be further enhanced by using more robust methods of optimal data combination testing.

For further studies, presented relationship between catchment land use and model efficiency should be taken as only indicative. For varying basins, individual testing of model performance should be made and evaluated. Ability of conceptual hydrological model to reflect rainfall-runoff process in the catchment strongly depends on the availability of highquality input data. Continuous hydrological gauging in the river catchment confluence is the basis for such input. Air temperature is relatively spatially consistent, therefore the number of stations for Morava Basin was adequate even when strict time series length requirements were applied. In contrast, precipitation is much more variable in space, thus the density of station network was not sufficient (about one station for every $100 \mathrm{~km}^{2}$ in the Morava Basin), in particular for smaller catchments. The success of calibration on individual catchment does not rely on the number of usable rainfall data sources, but on the availability of weather stations with sufficiently long data series suitably located in the area of interest. The suitability is not determined only by geographical proximity of the station, but especially by its appropriate location for representing the nature of rainfall for the area of the basin as a whole.

Software testing presented in this paper produced good results and confirmed, that Runoff Prophet is an effective tool for conceptual hydrological modelling. It also brought about many suggestions for further improvement of the methods used and upgrades of the software.

It was proved, that Runoff Prophet and the original water balance equations are usable in variable hydrological conditions of the Czech Republic. It is expected, that the software is suitable for rainfall-runoff modelling of diverse basins with similar conditions and characteristics as presented in the experiments described in this paper, whether in areas with temperate climate or worldwide.

\section{ACKNOWLEDGEMENTS}

We would like to express our appreciation to colleagues from the Czech Hydrometeorological Institute: G. Knozova for operative supply of climate data, P. Coufal for help with catchments classification, B. Barta for providing catchments characteristics and map and P. Benacek for help with data processing.

This research was funded by Climate Change Uncertainty Propagation in Hydrologic and Water Management Applications research project number (FAST-S-18-5341). It is also the result of CHMI Department of Hydrology project of the internal intention.

Runoff Prophet can be downloaded and used for non-commercial purposes as freeware from following website: uvhk.fce.vutbr.cz/cs/software.php. 


\section{REFERENCES}

[1] Klimatická změna, CzechGlobe (Ústav výzkumu globální změny AV ČR v.v.i.), Brno. www.klimatickazmena.cz. Accessed on: 4 Dec. 2018.

[2] Czech Hydrometeorological Institute, Tisková zpráva 22.11.2018, Brno. portal.chmi.cz/informace-pro-vas/tiskove-zpravy/2018. Accessed on: 4 Dec. 2018.

[3] HEC-HMS. www.hec.usace.army.mil/software/hec-hms/.

[4] NOAA National Weather Service, NWSRFS User Manual Documentation, Silver Spring. www.nws.noaa.gov/ohd/hrl/nwsrfs/users_manual/htm/xrfsdocpdf.php.

Accessed on: 11 Jan. 2019.

[5] HySoft Brno. www.hysoft.cz.

[6] SWAT. https://swat.tamu.edu/.

[7] Beven, K., Lamb, R., Quinn, P., Romanowicz, R. \& Freer, J., TOPMODEL. Computer Models of Watershed Hydrology, ed. V.P. Singh, Water Resources Publications: Colorado, pp. 627-668, 1995.

[8] Knoppová, K., Srážko-odtokový proces v podmínkách klimatické změny. Master's thesis, Brno University of Technology, 2018.

[9] Wang, G.Q. et al., Simulating the impact of climate change on runoff in a typical river catchment of the Loess Plateau, China. Journal of Hydrometeorology, 14, pp. 15531561, 2013.

[10] Knoppová, K. \& Marton, D., Srážko-odtokový model pro dlouhodobé prognózy v podmínkách klimatické změny. Hospodaření s vodou v krajině, 2018.

[11] Knoppová, K., Runoff Prophet, Nástroj pro dlouhodobé hydrologické prognózy v podmínkách změny klimatu. Konferencie mladých odborníkov, 2018.

[12] Marton, D. \& Knoppová, K., Robust reliability assessment of water reservoir under uncertainty of climate change. HIC 2018 - 13th International Conference on Hydroinformatics, pp. 1316-1323, 2018.

[13] Zelinka, I., Umélá inteligence v problémech globální optimalizace. BEN-technická literatura: Prague, 2002.

[14] Appendix 1: Thornthwaite Method: Water balance on the Central Rift Valley; Universitat politecnica de Catalunya, UPCommons: Portal de coneixement obert de la UPC, Barcelona. https://upcommons.upc.edu/bitstream/handle/2117/89152/ Appendix 10.pdf?sequence=3\&isAllowed=y. Accessed on: 15 Jan. 2019.

[15] Chapter 3.1.3 Blaney-Criddle Method: Chapter 3: Crop water needs; Food and Agriculture Organisation of the United Nations, Rome. www.fao.org/docrep/ S2022E/s2022e07.htm\#. Accessed on: 15 Jan. 2019.

[16] Abbott, M.B. \& Refsgaard, J.C., Deterministic models. Distributed Hydrological Modelling, Kluwer Academic Publishers: Dordrecht, pp. 27-30, 1996.

[17] Moriasi, D.N., Arnold, J.G., Van Liew, M.W., Bingner, R.L., Harmel, R.D. \& Veith, T.L., Model evaluation guidelines for systematic quantification of accuracy in watershed simulations. Transactions of the ASABE, 50(3), pp. 885-900, 2007. 